Журнал «Герспективитаінноваціїнауки»

(Серія «Гедагогіка», Серія «Гиихологія»), Серія«Медицина»

№5(5) 2021

УДК 37.03:378.1

https://doi.org/10.52058/2786-4952 -2021-5(5)-88-98

Беркещук Інна Степанівна кандидат філологічних наук, доцент, доцент кафедри української мови, Кам'янець-Подільський національний університет імені Івана Огієнка, вул. Огієнка, 61, м. Кам'янець-Подільський, 32300, тел.: (067) 700-30-36, e-mail: bercesinna@gmail.com, https://orcid.org/0000-0002-4772-7480

Степаненко Олена Костянтинівна кандидат філологічних наук, доцент, доцент кафедри соціально-гуманітарної освіти, Комунальний заклад вищої освіти «Дніпровська академія неперервної освіти» Дніпропетровської обласної ради», вул. Володимира Антоновича, 70, м. Дніпро, 49006, тел.: (067) 567-58-27, e-mail: olena.step@ukr.net, https://orcid.org/0000-0003-0887-5808

Старостенко Олена Валентинівна кандидат біологічних наук, доцент кафедри біології, Національний медичний університет імені О.О. Богомольця, проспект Перемоги, 34, м. Київ, 01601, тел.: (095) 560-57-14, e-mail: elenastarostenko1207@gmail.com, https://orcid.org/0000-0001-6528-5017

\title{
МОТИВАЦІЯ ЯК ЧИННИК ПІДВИЩЕННЯ ЯКОСТІ НАВЧАННЯ СТУДЕНТІВ: ДОСВІД ЗВО
}

Анотація. Формування позитивної мотивації у студентів, як майбутніх фахівців, до обраної ними професії не є можливим без належної мотивації до навчально-пізнавальної діяльності, яка тісно пов'язана із цим фахом. Серед важливих мотиваційних елементів, які широко застосовуються ЗВО для спонукання студентів до навчання, i, тим самим, до підвищення якості такого навчання, слід вирізняти мотиви, потреби у навчанні та сенс такого навчання. Ключову роль у формуванні позитивної мотивації у студентів до навчання відіграє застосування у навчальному процесі сучасних інтерактивних методів та інструментів. Важливе місце у процесі формування позитивної мотивації у студентів до навчання посідають психологічні фактори, зокрема психологопедагогічні, особистісні, соціально-психологічні та професійні. Факторами, що сповільнюють процес заохочення студента до здобуття ним знань, є суттєво високі вимоги, які ставлять ЗВО до навчального процесу та низький рівень оплати праці професії, яку студенти здобувають. Мотивація студентів до навчання - це шлях до професійної діяльності у перспективі. Не менш важливого значення у формуванні позитивної мотивації у студентів відіграє процедура актуалізації самостійної роботи студентів. У підвищенні ефективності освоєння навчального матеріалу студентами під час самостійної роботи визначальну роль відіграє належний рівень матеріального та інформаційного забезпечення навчального процесу. Мотивація $\epsilon$ досить 
складним, але водночас дієвим процесом, успішне проходження етапів якого впливає на самореалізацію, саморозвиток та самовдосконалення студентів. Для формування позитивної мотивації у студентів до навчання на базі Кам'янецьПодільського національного університету імені Івана Огієнка, Комунального закладу вищої освіти «Дніпровська академія неперервної освіти» Дніпропетровської обласної ради» та Національного медичного університету імені О.О. Богомольця розробляються та впроваджуються на практиці різні тренінгові програми, в основу яких закладено розвиток у студентів мотивації до навчання.

Ключові слова: мотивація, якість навчання, знання, вміння, навички, заклад вищої освіти.

Berkeshchuk Inna Stepanivna Candidate of Philological Sciences, Associate Professor, Associate Professor at the Department of Ukrainian Language, Kamianets-Podilskyi Ivan Ohiienko National University, Ohiienko St., 61, Kamianets-Podilskyi, 32300, tel.: (067) 700-30-36, e-mail: bercesinna@gmail.com, https://orcid.org/0000-0002-4772-7480

Stepanenko Olena Kostiantynivna Candidate of Philological Sciences, Associate Professor, Associate Professor at the Department of Social and Humanitarian Education, Communal Institution of Higher Education «Dnipro Academy of Continuing Education» of Dnipropetrovsk Regional Council, Vladimir Antonovich St., 70, Dnipro, 49006, tel.: (067) 567-58-27, e-mail: olena.step@ukr.net, https://orcid.org/0000-0003-0887-5808

Starostenko Olena Valentynivna Candidate of Biological Science, Associate Professor at the Department of Biology, Bogomolets National Medical University, Peremogy Ave., 34, Kyiv, 01601, tel.: (0950 560-57-14, e-mail: elenastarostenko1207@gmail.com, https://orcid.org/0000-0001-6528-5017

\section{MOTIVATION AS A FACTOR OF IMPROVING THE QUALITY OF STUDENT EDUCATION: THE EXPERIENCE OF HEI}

Abstract. The formation of positive motivation in students, as future professionals, to their chosen profession is not possible without proper motivation for educational and cognitive activities, which are closely related to this profession. Among the important motivational elements that are widely used by HEAs to motivate students to learn, and thus to improve the quality of such learning, it is necessary to distinguish the motives, needs for learning and the meaning of such learning. The use of modern interactive methods and tools in the educational process plays a key role in the formation of positive motivation in students to study. An important place in the process of forming a positive motivation of students to study is occupied by psychological factors, including psychological and pedagogical, 
personal, socio-psychological and professional. Factors that slow down the process of encouraging students to acquire knowledge are significantly high requirements that place the free economic zone in the educational process and low pay for the profession that students acquire. Motivating students to study is a way to professional activity in the future. The procedure of actualization of students' independent work plays no less important role in the formation of positive motivation in students. The appropriate level of material and information support of the educational process plays a decisive role in improving the efficiency of learning material by students during independent work. Motivation is a rather complex, but at the same time effective process, the successful completion of stages of which affects the self-realization, self-development and self-improvement of students. To form a positive motivation for students to study at Kamianets-Podilskyi Ivan Ohiienko National University, the Communal Institution of Higher Education «Dnipro Academy of Continuing Education» of Dnipropetrovsk Regional Council and the Bogomolets National Medical University training programs are developed and implemented in practice, which are based on the development of students' motivation to study.

Keywords: motivation, quality of education, knowledge, skills, institution of higher education.

Постановка проблеми. Підвищення рівня конкурентоспроможності країни не можливе без висококваліфікованих працівників. Для того, щоб стати висококваліфікованим фахівцем, необхідно мати належний рівень професійної підготовки, здобуття якого можливе за рахунок формування позитивної мотивації у фахівця до навчання. Практика показує, що формування позитивної мотивації у студентів, як майбутніх фахівців, до обраної ними професії не $\epsilon$ можливим без належної мотивації до навчально-пізнавальної діяльності, яка тісно пов'язана із цим фахом. Доцільно зауважити, що формування позитивної мотивації до навчання відбувається вже у деяких студентів на початку навчання у закладі вищої освіти, оскільки такі студенти здійснили свідомий вибір майбутнього фаху та виявляють бажання здобувати нові знання та освоювати нові вміння і навички. Такі студенти вже знають, для чого їм необхідні знання, адже вони у перспективі зможуть ї використати у професійній діяльності. Проте, серед багатьох студентів $є$ і такі, які вступають у ЗВО, але вони перед собою не бачать цілі одержувати нові знання, здобувати нові навички. Тому, у таких студентів $є$ досить низький рівень мотивації до здобуття вищої освіти. Рівень якості навчання таких студентів $є$ доволі низьким, що негативно позначиться на їх майбутній професійній діяльності.

3 огляду на важливість проблематики мотивації студентів до навчання, в основі актуальності тематики цього дослідження лежатиме розкриття особливостей мотиваційного процесу та його елементів як важливої складової підвищення якості навчання студентів. 
Аналіз останніх досліджень і публікацій. Проблеми мотивації студентів до навчання та шляхи вирішення цих проблем лежать в основі досліджень багатьох зарубіжних та вітчизняних науковців. Зокрема грунтовні дослідження у такому напрямку здійснюють Л. Беш [1], О. Беш [1], Н. Боброва [2], О. Ганчо [2], М. Долінна [3], Б. Дмитришин [1], С. Зачепило [2], Н. Коваленко [2], Т. Кузнєцова [4], I. Ляшенко [5], О. Мацюва [1], В. Мельман [6], М. Моклюк [7], А. Сільвейстр [7], Т. Шеховцева [3], Н Черняк [8], О. Яскевич [1] та інші.

Метою наукової статті $\epsilon$ дослідження особливостей формування мотивації у студентів до навчання як чинника підвищення якості такого навчання, виходячи із досвіду ЗВО.

Виклад основного матеріалу дослідження. Серед важливих мотиваційних елементів, які широко застосовуються ЗВО для спонукання студентів до навчання, i, тим самим, до підвищення якості такого навчання, слід вирізняти мотиви, потреби у навчанні та сенс такого навчання. Студенти, здобуваючи нові знання, мають постійно самовдосконалюватись, самовиражатись та самореалізуватись. Особливе значення у формуванні позитивної мотивації студентів до навчання відіграє їх взаємодія із викладачами, які безпосередньо виступають суб'єктами донесення знань до студентів. Сприятливе співробітництво між викладачем та студентом завжди буде приносити позитивний результат та впливатиме на формування у студента бачення того, що знання потрібні для його майбутньої професійної діяльності.

Ключову роль у формуванні позитивної мотивації у студентів до навчання відіграє застосування у навчальному процесі сучасних інтерактивних методів та інструментів. Так, навчання студентів завдяки застосуванню інтерактивних методик у такому процесі створює студенту додаткові можливості і певним чином полегшує шлях засвоєння нового матеріалу. Навчальний процес, побудований на засадах інтерактивності, усучаснює методику викладення навчального матеріалу, адже сприйняття та засвоєння такого матеріалу із застосуванням мультимедійних технологій $є$ більш ймовірним, ніж коли у навчальному процесі використовуються тільки традиційні методи навчання. 3 огляну на зазначене, а також, враховуючи інформацію, представлену у [3], навчання на базі інтерактивних технологій - це дієвий та ефективний інструмент формування та підвищення мотивації у студентів до освоєння навчального матеріалу.

Розглядаючи особливості формування мотивації у студентів до навчання, доцільно відзначити, що важливе місце у такому процесі посідають психологічні фактори, які, своєю чергою, формуються під впливом [6]:

1) психолого-педагогічних чинників, серед яких: а) мотиви навчальної діяльності; б) особливості організації діяльності студентів до навчання на основі використання різних методик навчання; в) використання традиційних та інтерактивних методик навчання; г) рівень професіоналізму викладача; 
д) умови, в яких проходить навчальний процес;

2) особистісних чинників, а саме: a) мотиваційної структури, якою керується студент у навчальному процесі; б) прагнення до самовдосконалення та самореалізації; в) рівень креативності студента; г) відмінний фізіологічний розвиток студента; д) психологічний клімат у сім 'і;

3) соціально-психологічних факторів, серед яких: а) соціальнопсихологічний клімат у навчальному колективі; б) особливості виховання; в) соціально-психологічний клімат у студентському колективі; г) взаємодія між викладачем та студентами;

4) професійних, зокрема на основі: а) мотиваційної специфіки до здобуття навиків професійної діяльності; б) ставлення до себе як до професіонала; в) ставлення до професійної діяльності, яку студент прагне здобути.

На процес формуванні мотивації студентів до навчання чинять вплив як позитивні, так і негативні фактори. Факторами, що сповільнюють процес заохочення студента до здобуття ним знань, є суттєво високі вимоги, які ставлять ЗВО до навчального процесу та низький рівень оплати праці професії, яку студенти здобувають [1].

Своєю чергою, формування позитивної мотивації у студентів до навчання відбувається під впливом різних факторів, а також через спеціальні умови. Так, акцентуючи увагу на інформації, представленій у джерелі [8], важливими сприятливими умовами формування позитивної мотивації у студентів до навчання є: професіоналізм викладачів; сприйняття викладачами студентів як компетентних особистостей; сприйняття викладачами самовираження студентів; допомога у розвитку у студентів позитивних емоцій до навчання; досконало зорганізований навчальний процес; використання сучасних методик стимулювання навчально-пізнавальної діяльності; бачення та чітке усвідомлення цілей здобуття вищої освіти; доступність навчального матеріалу тощо.

Завдяки мотивації студенти усвідомлюють те, що вони повинні більш грунтовніше та із захватом освоювати нові знання. Мотивація повинна формувати у студентів бачення їх незалежності у здобутті освіти незалежно від впливу на цей процес різних несприятливих факторів [7]. Акцентуючи увагу на зазначеному вище, треба зауважити, що мотивація студентів до навчання - це шлях до професійної діяльності у перспективі.

Мотивація студентів у ЗВО носить навчально-професійний характер. Студенти, вступивши до ЗВО, керуються мотивами здобуття навиків майбутньої професії. 3 огляду на те, мотиви здобуття навиків майбутньої професії мають виступати однією із головних цілей формування позитивної мотивації у студентів до навчання. Спільно із мотивами до навчання, мотивація здобуття навиків майбутньої професії формує процес мотивації студентів до навчально-пізнавальної діяльності.

3 огляду на зазначене вище, процес мотивації до навчально-пізнавальної діяльності формується під впливом багатьох мотивів навчально-пізнавальної 
діяльності. Під такими мотивами розуміють намагання студентів досягати відповідного рівня розвитку у здобутті освіти і у професійній діяльності. У систему проходження цього процесу закладено здобуття глибоких, міцних та різноманітних загальнонаукових і професійних знань, навиків та умінь [4].

Варто зазначити, що мотивація студентів до навчально-пізнавальної діяльності не має бути для них проблемою. Студенти для себе повинні, перш за все, зрозуміти, для чого вони опановують майбутній фах. Лише, зрозумівши цінність науки, як центр опанування майбутньої професії, студенти зможуть вирішити проблему формування у них позитивної мотивації до навчання.

Засвоєння нового навчального матеріалу відбувається за рахунок формування у студентів позитивної мотивації до навчання. Аналізуючи алгоритм процесу засвоєння нових знань студентом, потрібно зазначити, що він реалізується через систему засвоєння студентом окремих складових цілісного знання, яке має здобути студент. Викладач для кращого засвоєння студентом знань має чітко, логічно та послідовно викладати навчальний матеріал. Студент, своєю чергою, має запам'ятовувати викладений викладачем матеріал до часу наступного викладення навчального матеріалу. За такого алгоритму викладення навчального матеріалу, процес освоєння знань студентом буде синхронним, тому, як правило, багато студентів втрачають інтерес до навчання, оскільки воно є, в першу чергу, одноманітним.

Підвищити інтерес студентів до навчання i, тим самим, скоротити одноманітність викладення навчального матеріалу викладачами студентам можна за рахунок правильного викладення iз конкретикою розкриття навчального матеріалу. За таких умов студенти стають більш зацікавленими у освоєнні навчального матеріалу, навчальна діяльність поступово формує у студентів бажання творчості та ініціативності до викладення своїх знань на практиці. Позитивне сприйняття студентами навчального предмета найперше залежить від змісту викладеного навчального матеріалу та методики, за якою здійснюється безпосередньо процес викладення такого матеріалу викладачами студентам [2].

Практика 3ВО у напрямку формування у студентів мотивації до навчання побудована на багатьох методологічних принципах, зокрема на принципі застосування інтерактивних методів у навчальному процесі для покращеного викладення навчального матеріалу та освоєння такого матеріалу студентами. Визначальне значення для підвищення мотивації студентів має участь студентів у різних конференціях, на яких вони можуть доповідати. Цей стимулюючий захід до навчання дозволяє формувати у студентів впевненість у собі, у власних силах, переконаннях. Студент, таким чином, формує власну особистість.

Окрім участі у конференціях, для формування позитивної мотивації у студентів до навчання визначальну роль відіграє участь у діяльності студентських наукових гуртків та студентських товариств [1].

Не менш важливого значення у формуванні позитивної мотивації у 
студентів відіграє процедура актуалізації самостійної роботи студентів. Для полегшення процесу здобуття студентами нових знань, вмінь та навичок у контексті самостійної роботи потрібно чітко визначити рамки відведеного студентам навчального матеріалу, який вони мають освоїти під час самостійної роботи.

У підвищенні ефективності освоєння навчального матеріалу студентами під час самостійної роботи визначальну роль відіграє належний рівень матеріального та інформаційного забезпечення навчального процесу. Студенти мають навчатися виробляти навички самостійної роботи із методичними матеріалами, різного роду підручниками, у яких міститься навчальний матеріал по кожному із курсів. Студенти також мають ефективно оперувати інформацією за результатами проходження курсів у онлайн-режимі. У підсумку в них мають закарбуватись знання, які б вони змогли висвітлити у своїх конспектах, опрацювавши для цього різні навчальні джерела [4]

Не менш важливого значення у підвищення якості навчання студентів посідає саморозвиток студентів як особистостей. Самоутвердження студента як особистості також має виходити із впливу на цей процес мотиваційних факторів. Так, згідно інформації, наведеної у джерелі [5], мотиваційною складовою професійного саморозвитку студентів $є$ потреби, які вони відчувають під час здобуття нових знань, вмінь, навичок, зокрема:

1) потреба у ставленні студента до себе як до індивіда (на таких засадах формується готовність студентів до переорієнтації особистої життєдіяльності до пошуку нових потенційних можливостей у контексті досягнення максимальної професійної самореалізації);

2) потреба у належному мотиваційному забезпеченні, в основі якої лежить проходження ряду етапів, починаючи від етапу навчально-професійної підготовки, на якому відбувається вплив особистісних характеристик на рівень формування соціального досвіду та компетентності студента як індивіда, його індивідуальних характеристик, особливостей i детермінант здійснення професійної діяльності у перспективі;

3) потреба у зорієнтованості на необхідності постійного самовдосконалення шляхом здобуття безперервної професійної освіти;

4) потреба у внутрішньому поєднанні структурних складових психіки студента як особистості, зокрема в її основу має бути закладено забезпечення конструктивної взаємодії із навколишнім середовищем з ціллю одержання належного результату від здійснення професійної діяльності (така потреба у жодному разі не має обмежуватись тільки набутим досвідом, а має бути націлена на професійне зростання через реалізацію інтересів, прагнень, переконань, здібностей студента як особистості; за рахунок формування активної позиції студента у пізнанні довкілля, самопізнанні, у розумінні підвищення духовного та інтелектуального потенціалу).

У ході розкриття мети статті було досліджено особливості формування позитивної мотивації у студентів до навчання на прикладі Кам'янець- 
Подільського національного університету імені Івана Огієнка, Комунального закладу вищої освіти «Дніпровська академія неперервної освіти» Дніпропетровської обласної ради» та Національного медичного університету імені О.О. Богомольця.

Вивчення особливостей мотиваційного процесу, який застосовується у вищезазначених закладах вищої освіти, показало, що студенти, які здобувають вищу освіти у цих ЗВО, мають, перш за все, чітко виражений інтерес до освоєння знань, які вони зможуть використати у перспективі подальшого працевлаштування за обраним ними фахом. Серед інших мотиваційних складових прагнення студентів здобувати знання у цих ЗВО є:

1) бажання студентів у перспективі знайти свою професійну нішу на ринку праці;

2) прагнення бути корисним іншим особам, які мають потребу у послугах, які студенти надаватимуть, здобувши професійний фах.

Проте, не всі студенти, що здобувають вищу освіту, керуються мотивом бути корисним іншим. Дехто обирає професію, опираючись на їі престижність, дехто - через те, що так кажуть рідні. Серед загального числа студентів $\epsilon$ і такі студенти, які обрали професію через випадковість, до прикладу, змогли вступити на бюджетну форму навчання чи через інші обставини, що спонукали їх до такого вибору.

Враховуючи реалії сьогодення, перед кожним закладом вищої освіти, у тому числі і перед Кам'янець-Подільським національним університетом імені Івана Огієнка, Комунальним закладом вищої освіти «Дніпровська академія неперервної освіти» Дніпропетровської обласної ради» та Національним медичним університетом імені О.О. Богомольця стоїть завдання, яке полягає у формуванні позитивної мотивації у студентів до здобуття професійних знань, вмінь та навичок. Студенти повинні чітко усвідомлювати розуміння потреби опанування професійних знань, умінь і навичок. Тому професійна мотивація до формування у студентів навчально-пізнавальної діяльності має, перш за все, носити розгорнутий і наполегливий характер. Студенти, здобуваючи освіту, мають отримувати не тільки користь від навчання, але і своєрідну насолоду, яка, своєю чергою, має переростати тільки у позитивні емоції та бажання до здійснення професійної діяльності у перспективі.

Тому мотивація студентів до досягнення ними успіху має базуватись на формуванні у них захоплення не тільки процесом навчання, але і майбутньою професією. Студенти повинні виявляти ініціативу до навчання і бачити та формувати навколо себе тільки творчу та водночас пізнавальну атмосферу. Студенти повинні демонструвати готовність до здійснення у перспективі успішної та водночас ефективної професійної діяльності.

Поряд з тим, потрібно відзначити і важливість формування у студентів мотивації самоствердження та мотивації демонструвати особисті досягнення як ті, що $є$ реальними, так i ті, що можуть бути реальними. У такому процесі студенти мають виявляти наполегливість, демонструвати високу емоційність 
по відношенню до своїх результатів.

Треба зауважити, що взаємодія навчально-пізнавальної діяльності, розумового розвитку і виховання впливає на формування інтересу студентів до навчання. Через пізнавальний інтерес, знання та можливості опановувати знання студенти формують особистий інтелект та виховують у собі різносторонньо розвинену особистість.

У відповідності до специфіки процесу формування позитивної мотивації до навчання, студентів потрібно поділяти на такі три класи:

1) студенти, які орієнтуються на здобутті різнобічної професійної підготовки та опануванні навиків пізнавальної діяльності у більш широкому контексті;

2) студенти, які орієнтуються на здобутті знань, вмінь та навичок, які можуть бути ними використані для здійснення вузькопрофільної професійної діяльності;

3) студенти, які не мають внутрішньої мотивації і тому їх пізнавальна активність $є$ мінімальною.

Таким чином, для формування позитивної мотивації у студентів до навчально-пізнавальної та професійної діяльності потрібно:

- чітко проявляти пізнавальну активність, інтелектуальну ініціативність та самостійність у ході прийнятті рішень стосовно вибору шляхів здобуття знань, вмінь та навиків;

- $\quad$ постійно примножувати об'єм внутрішнього світобачення та бути відкритим до пізнання нової інформації та ії̈ засвоєння із користю;

- $\quad$ орієнтуватись на перспективи професійного зростання, при цьому будуючи власний професійний шлях (для реалізації цього процесу студенти чітко повинні розуміти, для чого вони мають здобувати нові знання, вміння та навики);

- $\quad$ постійно підвищувати самооцінку та самокритичність, адже без цих якостей не можливо самоутвердитись у суспільстві;

- формувати потреби та із користю втілювати їх на практиці, реалізуючи, таким чином, особисті можливості.

Для формування позитивної мотивації у студентів до навчання на базі Кам'янець-Подільського національного університету імені Івана Огієнка, Комунального закладу вищої освіти «Дніпровська академія неперервної освіти» Дніпропетровської обласної ради» та Національного медичного університету імені О.О. Богомольця розробляються та впроваджуються на практиці різні тренінгові програми, в основу яких закладено розвиток у студентів мотивації до навчання. Беззаперечно слід відзначити той факт, що реалізація тренінгових програм націлена на формування не тільки внутрішньої, але і зовнішньої мотивації. В основі таких тренінгів закладено участь студентів у різних дискусіях, іграх, бесідах, а також у ситуаціях, якими вимагається вирішити проблемні завдання із прийняттям на цій основі виважених рішень.

До участі у тренінгах потрібно також запрошувати і випускників, що вже 
стали на перспективний професійний шлях розвитку. Запрошення випускників стане ефективним інструментом формування у студентів мотивації до навчання, адже вони бачитимуть реальний приклад того, як можна стати успішним, але при цьому треба багато вчитись, освоювати нові знання, здобувати нові вміння. Завдяки таким тренінгам студенти зможуть чітко окреслити особисті пріоритети у професійному розвитку.

Поряд 3 тим, треба зауважити, що окрім мотиваційних інструментів морального характеру, важливе значенні у підвищенні мотивації до навчання набуває надання можливості студентам здобути різні іменні стипендії, адже отримання додаткових коштів - це хороший мотиваційний інструмент у здобутті нових знань, вмінь та навичок.

Висновки. За результатами проведеного дослідження встановлено, що мотивація навчально-пізнавальної діяльності - це ефективний інструмент підвищення якості навчання студентів.

Дослідження дозволяють зазначити, що мотивація є досить складним, але водночас дієвим процесом, успішне проходження етапів якого впливає самореалізацію, саморозвиток та самовдосконалення студентів.

Визначивши особливості мотивації студентів до навчання на прикладі Кам'янець-Подільського національного університету імені Івана Огієнка, Комунального закладу вищої освіти «Дніпровська академія неперервної освіти» Дніпропетровської обласної ради» та Національного медичного університету імені О.О. Богомольця Мотивація, потрібно зробити висновок про те, що перш за все, головним інструментом формування позитивної мотивації студентів до навчання має насамперед виступати розуміння використання здобутих студентами знань, умінь та навичок на практиці, тобто на шляху їх професійного зростання.

У перспективі наступних розвідок передбачено розкрити особисте бачення студентів щодо того, що на їх, думку, мотивує їх здобувати нові знання, вміння та навички. Дослідження передбачено провести, використовуючи метод анкетування. Інформація, отримана за результатами опрацювання анкет, дасть можливість чітко визначити позицію студентів щодо того, як можна їх мотивувати до навчально-пізнавальної діяльності.

\section{Лimepamypa:}

1. Беш Л.В., Дмитришин Б.Я., Беш О.М., Яскевич O.I., Мацюра O.I. Сучасні можливості підвищення мотивації студентів до навчання. Львівський клінічний вісник. 2017. № 1. C. 60-64.

2. Коваленко Н.П., Боброва Н.О., Ганчо О.В., Зачепило С.В. Мотивація студентів як запорука успішного професійного розвитку. Медична освіта. 2020. № 3. С. 43-48.

3. Шеховцева Т.Г., Долінна М.О. Інтерактивні методи навчання як основа мотивації студентів в умовах сучасного педагогічного процесу. Актуальні питання сучасної медицини: Вісник Української медичної стоматологічної академії. 2019. № 1. С. 105-108.

4. Кузнєцова Т. Мотивація навчання. Нова педагогічна думка. 2013. № 1.2. С. 37-39. 
5. Ляшенко І.В. Формування професійної мотивації студентів до успішної фахової діяльності. Народна освіта: Електронне наукове фахове видання. 2013. Випуск 1 (19). https://www.narodnaosvita.kiev.ua/?page_id=1076.

6. Мельман В. Психологічні фактори мотивації навчально-професійної діяльності студентів вищих навчальних закладів. Новий колегіум. 2009. №6. С. 56-59. http://eprints.kname.edu.ua/42980/1/Melman0001.pdf.

7. Сільвейстр А., Моклюк М. Мотивація навчання студентів як психолого-педагогічна проблема. Наукові записки. Серія: Проблеми методики фізико-математичної і технологічної освіти. 2016. Випуск 5. С. 152-158.

8. Черняк Н.О. Формування мотивації студентів до навчання у ВНЗ. Проблеми інженерно-педагогічної освіти. 2013. № 38-39. С. 388-393.

\section{References:}

1. Besh L.V., Dmytryshyn B.Ja., Besh O.M., Jaskevych O.I., Macjura O.I. (2017). Suchasni mozhlyvosti pidvyshhennja motyvaciji studentiv do navchannja [Modern opportunities to increase students' motivation to study]. Ljvivsjkyj klinichnyj visnyk - Lviv Clinical Bulletin, 1, 60-64 [in Ukrainian].

2. Kovalenko N.P., Bobrova N.O., Ghancho O.V., Zachepylo S.V. (2020). Motyvacija studentiv jak zaporuka uspishnogho profesijnogho rozvytku [Motivation of students as a guarantee of successful professional development]. Medychna osvita-Medical education, 3, 4348 [in Ukrainian].

3. Shekhovceva T.Gh., Dolinna M.O. (2019). Interaktyvni metody navchannja jak osnova motyvaciji studentiv v umovakh suchasnogho pedaghoghichnogho procesu [Interactive teaching methods as a basis for motivating students in the modern pedagogical process]. Aktualjni pytannja suchasnoji medycyny: Visnyk Ukrajinsjkoji medychnoji stomatologhichnoji akademiji - Current issues of modern medicine: Bulletin of the Ukrainian Medical Dental Academy, 1, 105-108 [in Ukrainian].

4. Kuznjecova T. (2013). Motyvacija navchannja [Motivation of learning]. Nova pedaghoghichna dumka - New pedagogical thought, 1.2, 37-39 [in Ukrainian].

5. Ljashenko I.V. (2013). Formuvannja profesijnoji motyvaciji studentiv do uspishnoji fakhovoji dijaljnosti [Formation of professional motivation of students to successful professional activity]. Narodna osvita: Elektronne naukove fakhove vydannja - Public education: Electronic scientific professional publication, 1 (19). www.narodnaosvita.kiev.ua. Retrieved from https://www.narodnaosvita.kiev.ua/?page_id=1076 [in Ukrainian].

6. Meljman V. (2009). Psykhologhichni faktory motyvaciji navchaljno-profesijnoji dijaljnosti studentiv vyshhykh navchaljnykh zakladiv [Psychological factors of motivation of educational and professional activities of students of higher educational institutions]. Novyj koleghium - New college, 6, 56-59. eprints.kname.edu.ua. Retrieved from http://eprints.kname.edu.ua/42980/1/Melman0001.pdf [in Ukrainian].

7. Siljvejstr A., Mokljuk M. (2016). Motyvacija navchannja studentiv jak psykhologhopedaghoghichna problema [Motivation of student learning as a psychological and pedagogical problem]. Naukovi zapysky. Serija: Problemy metodyky fizyko-matematychnoji i tekhnologhichnoji osvity - Proceedings. Series: Problems of methods of physical-mathematical and technological education, 5, 152-158 [in Ukrainian].

8. Chernjak N.O. (2013). Formuvannja motyvaciji studentiv do navchannja u VNZ [Formation of students' motivation to study at the university]. Problemy inzhenerno-pedaghoghichnoji osvity Problems of engineering and pedagogical education, 38-39, 388-393 [in Ukrainian]. 